\title{
Sintak Arsitektur Kampung Pengrajin Batik Gedok (Studi kasus Dusun Ngluwuk, Kec. Kerek, Kab. Tuban)
}

\author{
Chairil Budiarto Amiuza \\ Jurusan Arsitektur Fakultas Teknik Universitas Brawijaya \\ chairilbudiartoamiuza@yahoo.co.id
}

\begin{abstract}
Abstrak
Arsitektur Kampung pengrajin Batik gedok ini, nampaknya yang menonjol adalah konfigurasi visualnya, sehingga memberikan kekhasan dan keunikan serta menunjukkan potensinya. Konfigurasi visual berupa simbol simbol arsitektur yang perlu mendapat perhatian untuk dikaji, sehingga kajian ini dapat menelusuri unsur-unsur dan prinsip-prinsip susunan arsitektural kampung tersebut. Metode sintaksis diperoleh gambaran pengelompokan obyek-obyek visual yang ada di wilayah studi dalam rentang kesesuaiannya dengan bahasa arsitekturnya. Hasilnya, Konfigurasi dan interelasi visual elemen elemen Arsitektural diantaranya dari skala lingkungan, rumah tinggal sampai ragam hias Kampung pengrajin batik Gedok, terdapat keragaman dan keseragaman yang khas budaya bermukim mereka.
\end{abstract}

Kata Kunci: Semiotika, kampung, pengrajin Batik gedok, sintaksis, Semantik, prakmatik

\section{Pendahuluan}

Lingkungan permukiman dan rumah tinggal pengrajin batik gedok ini, bila dihubungkan dengan ke-mampuan artistik dan produktif peng-huninya dapat dipastikan nampak memiliki kehasan dan keunikan tersendiri. Rumah tinggal mereka terdiri dari lantai bambu, struktur kayu, beratap genteng dan kebanyakan dihiasi ragam hias yang artistik pula. Lingkungan permukiman yang tertata, bangunan rumah tinggal yang artistik dan kegiatan yang produktif dari desa pengrajin Batik gedok ini, nampak memiliki unsur unsur dan prinsip prinsip arsitektural yang lengkap, khas dan komprehensif. Dengan demikian arsitektur kampung Pengrajin Batik gedok ini perlu ditelusuri lebih lanjut kebe-radaannya dari beberapa sudut kajian, disamping kajian tentang Kampung ini masih terbatas, apalagi bila ada gagasan dari pihak manapun untuk dikembangkan dalam tautan yang lain.

Arsitektur Kampung Pengrajin Batik gedok ini, nampaknya yang menonjol adalah konfigurasi visualnya, sehingga memberikan kehasan dan keunikan serta menunjukkan potensinya. Konfigurasi visual ini yang terdiri dari simbol simbol atau tanda tanda arsitektur yang perlu mendapat perhatian untuk dikaji, sehingga kajian ini dimulai dari konfigurasi visualnya yang dapat menelusuri hubungan, makna dan fungsi bagi masyarakatnya. Kajian melalui tanda tanda visual atau penelusuran secara semiotika dalam ranah arsitektural sebagai upaya mengajak masyarakat memahami karyanya dengan cara berkomunikasi. akhirnya dapat mengungkapkan potensi seni dan budayanya yang bermanfaat bagi pelestarian, pe-ngembangan Keilmuan seni, budaya dan arsitektur. 
Penelitian ini bertujuan untuk mengetahui konfigurasi visual dan hubungan diantaranya dari skala lingkungan kampung, rumah tinggal dan ragam hias muka bangunan yang mewakili kampung pengrajin batik Gedok.

\section{Bahan dan Metode}

\subsection{Tinjauan Pustaka}

\subsubsection{Semiotika dalam Arsitektur}

Semikotika Arsitektural telah menjadi issu populer di kalangan teoritikus Arsitektur sejak tahun 1970, bahkan muncul istilah baru yaitu" Arsimiotik" ( Archisemiotics). Semiotika Arsitektur dapat memperkaya hasanah desain yang menyangkut tata bentuk dan ruang arsitektur.

Berdasarkan semiotika, Arsitektur dapat dibaca sebagai teks atau bahasa yang memiliki tata bahasa sintak, semantik dan prakmatik (Agus, 2003), maka unsur unsur desain arsitektur dapat dibaca sebagai berikut:

a. Dari segi Sintaksis, dapat dilihat unsur unsur arsitektur sebagai tanda tanda berupa bentuk dan ruang dan kerjasama antara tanda tanda tersebut.

b. Dari segi Semantik, dapat dilihat unsur unsur arsitektur sebagai tanda tanda berupa bentuk dan ruang dengan denotatumnya yang memiliki pula konotatumnya.

c. Dari segi prakmatik, dapat dilihat unsur unsur arsitektur sebagai tanda tanda berupa bentuk dan ruang memiliki arti bagi pe-makainya.

Ogden Richards (Dalam broadbent, 1980), meng-ilustrasikan hubungan tersebut sebagai segitga semiotika. Menurut Richards dalam semiotika arsitektur terdapat hubungan antara pemberi tanda (signifier), pesan yang terkandung dalam tanda (signified) dan fungsi tanda bagi pemakainya.

Sarana arsitektur yang digunakan memungkinkan manusia di dunia mewujudkan suatu kenyataan yang menurut arsitektur bentuk yang dibangun dan ruang yang ditata (Schulz, 1988). Demikian arsitektur adalah lingkungan yang terdiri dari bentuk yang dibangun dengan ruang yang ditata. Sudah ditetapkan bahwa ruang tertata mempunyai ciri umum, yang merupakan manifestasi terhadap berbagai tingkat lingkungan. Bentuk yang dibangun, ruang yang ditata dan tipe bangunan mencakup aspek sarana dan model hunian, jadi membentuk suatu "bahasa" sarana yang dapat memenuhi kebutuhan dalam membentuk multikeragaman diantaranya. Kita dapat menyebut studi ketiga konstituen interdependen tersebut dalam bahasa arsitektur Morfologi, topologi dan tipologi. Dengan demikian hasil karya arsitektur yang berwujud sosok massa, yang memberikan imajinasi dan menyiratkan daya komunikasi, mendorong manusia untuk menginterpertasikannya. Dengan kata lain manusia dapat mengkominikasikan sesuatu lewat karyanya dan manusia yang lain dapat pula menangkap maksud yang tersirat dalam karya tersebut (Siregar,2006).

Arsitektur adalah bahasa visual yang dapat berkomunikasi lewat sosok massanya. Makna komunikasi sangat penting dalam kehidupan manusia, dalam tautan arsitektur lewat bahasa visualnya, berupa tanda tanda, simbol simbol yang melekat pada sosok massanya. Suatu tanda bersifat sangat penting secara fundamental karena tanda tersebut mengabaikan perbedaan perbedaan kecil, melalui arti yang tetap membuat komunikasi bisa terlaksana ( schulz,1984).

Pengetahuan individu tidak mungkin didapatkan langsung dari semua obyek disekeliling ling-kungannya, sebagai gantinya dengan cara mengambil alih pengalaman pengalaman individu yang lain melalui tatanan tatanan simbol. Komunikasi terjadi atas simbol simbol tersebut dan manusia berusaha memahami atau mempersepsikannya. 
Persepsi bukanlah suatu kesan penerimaan yang passif, tetapi dapat mengubah fenomena dengan mengubah intensinya (schulz, 1984). Intensi adalah menekankan karakter aktif dalam kegiatan pengamatan. Mengamati, melihat dan merasakan berarti mempersepsikan, yaitu memilih salahsatu dari sekian banyak kemungkinan intensional.

Sebuah tatanan simbol dibangun melalui cara sedemikian rupa sehingga dapat beradaptasi dengan kawasan dari dunia obyek. Adaptasi ini dimungkinkan melalui sarana bentuk logis yang umum. Istilah simbolisasi, oleh sebab itu mengandung arti sebuah representasi dari pola hubungan dalam medium lain berdasarkan kemiripan struktural (Schulz,1984). Maka simbolisasi me-mungkinkan manusia menyampaikan maksudnya, demikian termasuk bentuk komunikasi atau bahasa visual. Arsitektur sebagai bentuk bahasa visual yang menyampaikan atau mengkomunikasikan nilai nilai yang diwujudkan sehingga dikenal dengan baik. Dengan kata lain arsitektur menyimbolkan obyek kultural.

\subsubsection{Pendekatan Semiotik dalam desain Arsitektur}

Penjelasan Semiotika, Arsitektur dan hubungannya dapat ditarik kesimpulan bahwa desain arsitektur apapun sebagai bahasa visual dapat ditelusuri atau dikaji lewat media bahasa tanda atau simbol yang terkadung didalamnya.

Sintaksis menegaskan pe-ngetahuan tentang gabungan elemen elemen atau unsur unsur desain. Unsur desain yang mana yang dapat dikombinasakan?, bagaimana caranya? Untuk apa?(Zahnd, 2009). Pembentukan elemen arsitektur berkaitan dengan penataan yang juga mengikuti aturan pola yang ada dalam sintaksia arsitektur. Sintaks arsitektur melibatkan mofologi dari empat aspek secara langsung sebagai berikut:

a. Sintaksis massa, memperhati-kan kombinasi semua elemen arsitektur yang berkaitan dengan massa.

b. Sintaksis ruang, mem-perhatikan kombinasi semua elemen arsitektur yang bersifat spasial atau berkaitan dengan ruang.

c. Sintaksis fungsi, memperhati-kan kombinasi semua elemen arsitektur yang bersifat atau berkaitan dengan fungsi.

d. Sintaksis konstruksi, mem-perhatikan kombinasi semua elemen arsitektur yang bersifat atau berkaitan dengan konstruksi.

\subsection{Metode Penelitian}

Penelitian ini menggunakan pendekatan kualitatif untuk menggali obyek-obyek visual dalam kawasan studi yang menurut pandangan masyarakat penduduk Kampung yang memiliki tanda-tanda atau simbol-simbol tertentu bagi lingkungan. Observasi lapangan dengan pengamatan, pengukuran, penggambaran dan dokumentasi visual obyek obyek arsitektural menyeluruh dan fokus yang penting didukung oleh responden terpilih berdasarkan penunjukan masyarakat setempat yang dipandang mewakili terkait obyek penelitian.

Data fisik dan non fisik dicatat, direkonstruksi menjadi peta, gambar gambar dan simbol simbol serta catatan catatan narasi. Hasil rekonstruksi tersebut dipaparkan kembali kepada masyarakat setempat, terutama ke penghuni, pemilik atau pemangku adat atau sosial setempat yang berhungan dengan fisik dan non fisik rekonstruksi tersebut. Hasil penilaian atau evaluasi rekonstruksi visual obyek arsitektur dari tingkat permukiman, rumah tinggal, detail ragam hias dari masyarakat setempat, di rekonstruksi kembali untuk dianalisis dan diinterpertasi melalui sintaksis, dalam bentuk laporan. 
Untuk mengetahui elemen-elemen lingkungan yang khas, unik dan memiliki simbol simbol yang dipahami setempat, data dari obsevasi lapangan dan hasil wawancara pertama diolah dengan menggunakan rekonstruksi konfigurasi visual dan narasi deskriptif. Dari hasil analisis akan diperoleh daftar elemen-elemen lingkungan atau obyek-obyek visual yang ada di lapangan dan disebutkan oleh para responden dalam wawancara dengan total jumlah sampel yang terpilih di lingkungan tersebut.

Selanjutnya sebagaimana diuraikan pada sub bab terdahulu, elemen-elemen lingkungan yang telah terpilih tersebut difoto, dimontase, digambar dan direkonstruksi untuk kemudian dinilai oleh masyarakat dengan menggunakan tabulasi gambar dan narasi. Data yang terkumpul pada bagian ini kemudian dianalisis dengan menggunakan metode sintaksis (semiotika bahasa rupa dan arsitektur) diperoleh gambaran pengelompokan obyek-obyek visual yang ada di wilayah studi dalam rentang kesesuaiannya dengan bahasa arsitekturnya.

\section{Hasil Dan Pembahasan}

\subsection{Gambaran Wilayah}

Kabupaten Tuban berada pada jalur pantura dan pada deretan pegunungan Kapur Utara. Pemerintahan Kabupaten Tuban ada sejak tahun 1293 (sejak pemerintahan Kerajaan Majapahit). Pusat pemerintahannya dulu adalah di Desa Prunggahan Kulon kecamatan Semanding dan kota Tuban yang sekarang dulunya adalah Pelabuhan karena dulu Tuban merupakan armada Laut yang sangat kuat. Asal nama Tuban sudah ada sejak pemerintahan Bupati Pertama yakni Raden Dandang Wacana. Tuban dulunya adalah tempat yang paling penting dalam masa Kerajaan Majapahit karena memiliki armada laut yang sangat kuat dan pada masa penyebaran Agama Islam. Di samping itu bangsa China dan Eropa terutama Belanda berlabuh di bandar Tuban untuk melakukan perdagangan pula terutama hasil pertanian, perkebunan, ladang dan hutan. Bandar Tuban yang pernah dikenal sebagai sebuah bandar besar di Jawa Timur berpengaruh jauh sampai kepedalaman Tuban, salahsatunya dampak perdagangan antar suku bangsa berupa pengaruh budaya berkehidupan spiritual, berkesenian dan bekerja keseharian bagi masyarakat pedalaman tersebut. Dusun Ngluwuk sebagai salahsatu dusun di pedalaman Tuban yang masih dapat dijumpai budaya tersebut dalam bentuk bermukim, berumah tinggal dengan pola, ragam dan kreasi yang khas sebagai dusun pengrajin tenun dan batik Gedok Tuban.

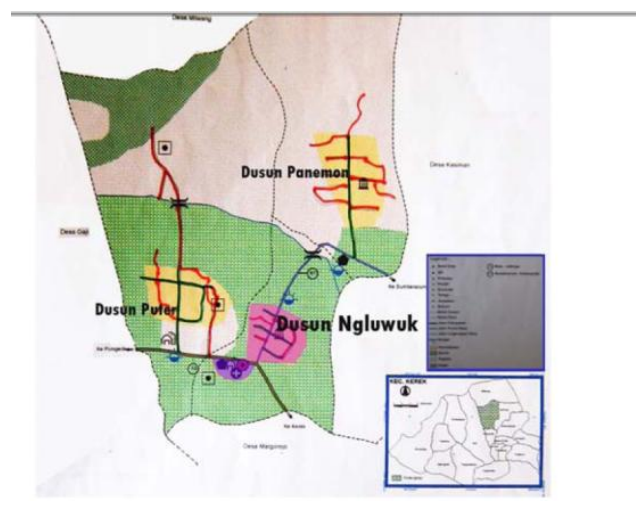

Gambar 1. Peta Lokasi Dusun Ngluwuk

Kecamatan kerek, Kab. Tuban

(Sumber: Kantor kecamatan Kerek) 
Kecamatan Kerek dibatasi sebelah utara kecamatan Tambakboyo, sebelah Selatan kecamatan Singgahan dan kecamatan Montong, sebelah Barat Kecamatan Tambak-boyo dan sebelah Timur kecamatan Merakuak. Dusun Ngluwuk di kecamatan Kerek tersebut, dapat dijangkau melalui akses jalan kecamatan berupa jalan aspal. Dusun Ngluwuk berada di tepi jalan kecamatan Kerek dan menuju ke dusun tersebut ditandai adanya Gapura warna putih dan bangunan gardu sebagai pintu masuk dusun tersebut. Jalan masuk dusun Kerek diterima oleh sebuah pohon, lapangan terbuka dan bangunan gardu kluster permukiman di tepi jalan menuju kluster kluster yang lain.

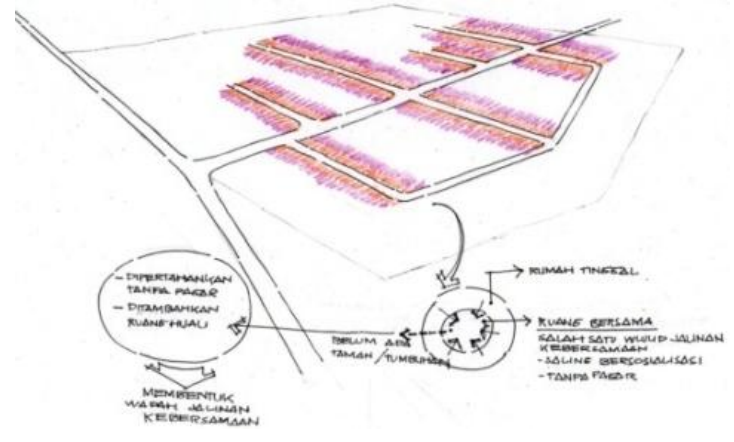

Gambar 2. Pola jalur dan cluster dusun Ngluwek, kec Kerek, Kab. Tuban

Pola pemukiman Dusun Ngluwuk tampak padat dengan pemanfaatan lahan untuk tempat tinggal dengan saling bersebelahan, saling berhadapan satu sama lain. Rumah rumah mereka tersusun secara cluster yang teratur dan mayoritas rumah menghadap jalan, membentuk ruang bersama di depan rumah, dan diantara dua rumah yang bersebelahan membentuk sirkulasi jalan setapak.

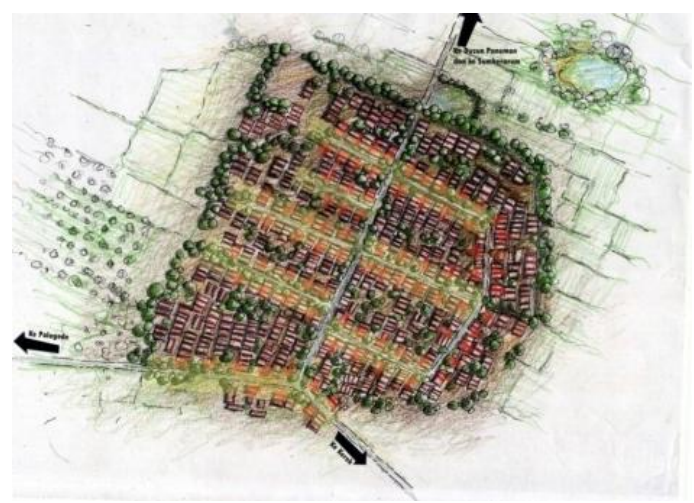

Gambar 3. Pola Masa \& ruang dusun Ngluwek, kec Kerek, Kab. Tuban

Massa kampung dusun Ngluwek terbentuk oleh susunan massa rumah tinggal yang berbanjar sepanjang ruang sirkulasi utama dan bersebelahan satu sama lain antara massa rumah tinggal berupa ruang sirkulasi setapak dan sekaligus batas keberadaan masing masing massa rumah tinggal. Massa massa tersebut berupa tempat tinggal, kandang dan langgar. Pada umumnya massa massa tersebut berdiri dengan konstruksi kayu dan bambu, hanya sebagian tersusun dari batukali dan batubata.

Ruang ruang kampung dusun Ngluwek juga mempunyai pola bujur-lintang sesuai pola massanya. Ruang terbuka utama dusun tersebut terdapat satu bangunan gardu, pepohonan, pagar batas jalan dusun dan bangunan rumah tinggal disekitarnya. Konstruksi ruang tersebut hanya berupa hamparan tanah keras. Ruang ruang terbuka yang lain berupa ruang ruang antara dan sejajar deretan halaman dan massa bangunan rumah tinggal. Ruang ruang terbuka dalam bentuk yang lain berupa lorong lorong antara dan melintang massa rumah tinggal. 


\subsection{Rumah Tinggal Kampung Dusun Ngluwuk}

Rumah tinggal penduduk dusun Ngluwuk umumnya bermassa tunggal, berbetuk persegi dengan bentuk atap pelana yang dikenal oleh mereka sebagai bentuk atap "Tekuk Lulang". Massa tunggal rumah tinggal tersebut besarannya beragam sesuai jumlah ruangan didalamnya, yang umumnya bertambah besar ke muka atau ke belakang rumah tinggal tersebut. Besaran massa diikuti oleh bertambahnya jumlah atap pelananya yang berulang dan sebagian ditambah tritisan depan rumah tinggal tersebut.

Muka bangunan rumah tinggal penduduk tersebut, sebagian besar memiliki bukaan berupa pintu masuk ditengahnya dan jendela disisi kiri kanan bukaan pintu tersebut dengan bentuk yang setangkup. Sebagian dilengkapi terasan dan halaman, sebagian yang lain tanpa terasan. Sebagian pula dilengkapi pagar pembatas, sebagian yang lain tanpa pagar pembatas, tapi langsung berupa penutup dinding anyaman bambu.

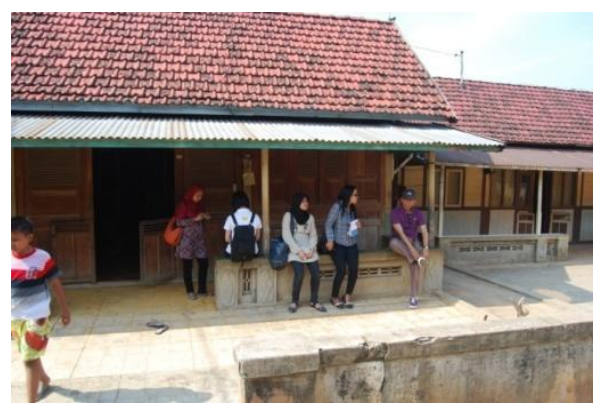

Gambar 4. Terasan \& halaman

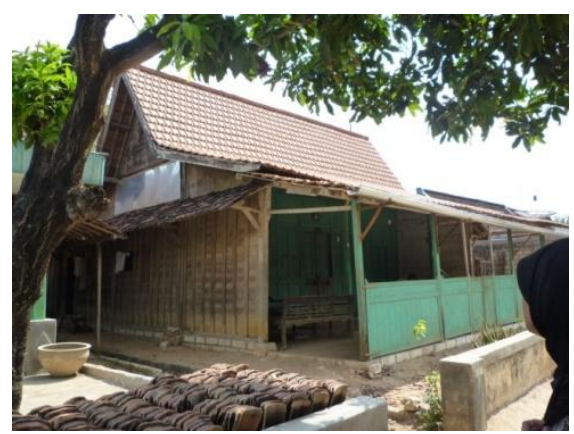

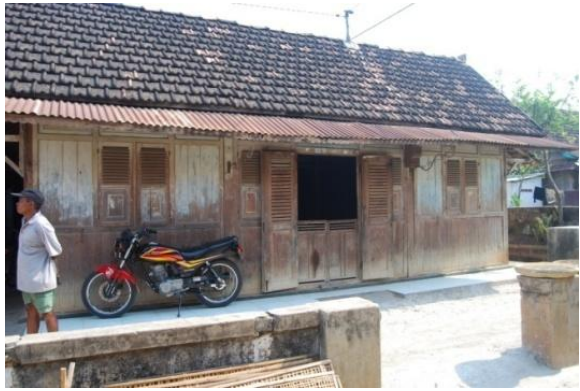

Gambar 5. Tanpa terasan

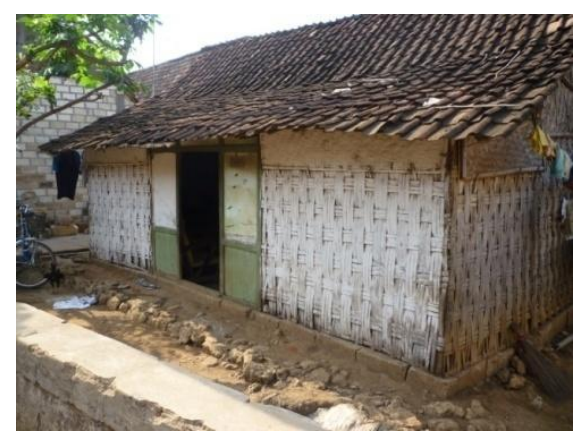

Gambar 6. Serambi depan dengan pagar Gambar 7. Serambi depan tanpa pagar

\subsection{Semiotika Arsitektur Dusun Ngluwuk}

\subsubsection{Sintaksis}

Kombinasi elemen elemen pembentuk Arsitektur permukiman dan Rumah Tinggal Dusun Ngluwuk dapat diuraikan melalui Sintaksis Massa, Sintaksia Ruang, Sintaksis Fungsi dan Sintaksis Konstruksinya.

a. Sintaksis Massa

Massa permukiman dibentuk oleh massa massa bangunan bersama (gapura,gardu, musholla, pepohonan) dan massa bangunan rumah tinggal penduduk dusun dan kandang piaraan. 


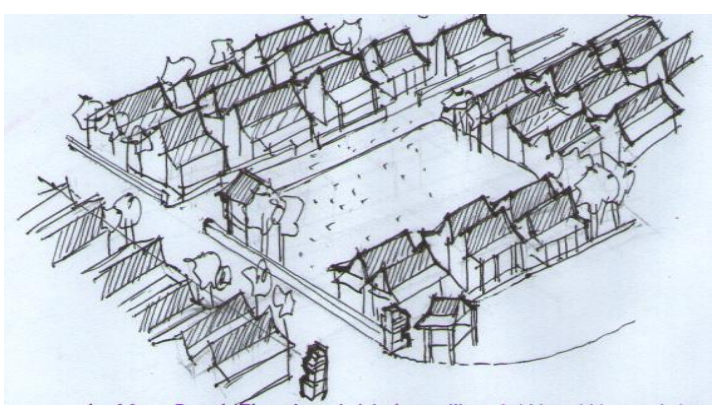

Gambar 8. massa permukiman dusun Ngluwuk

Massa Rumah Tinggal penduduk dusun dibentuk bidang bidang terbuka berupa pilar pilar tegak (Terasan), bidang bidang tegak tertutup (sebagian terbuka adanya pintu dan jendela) dan bidang bidang datar - miring tertutu (Atap)
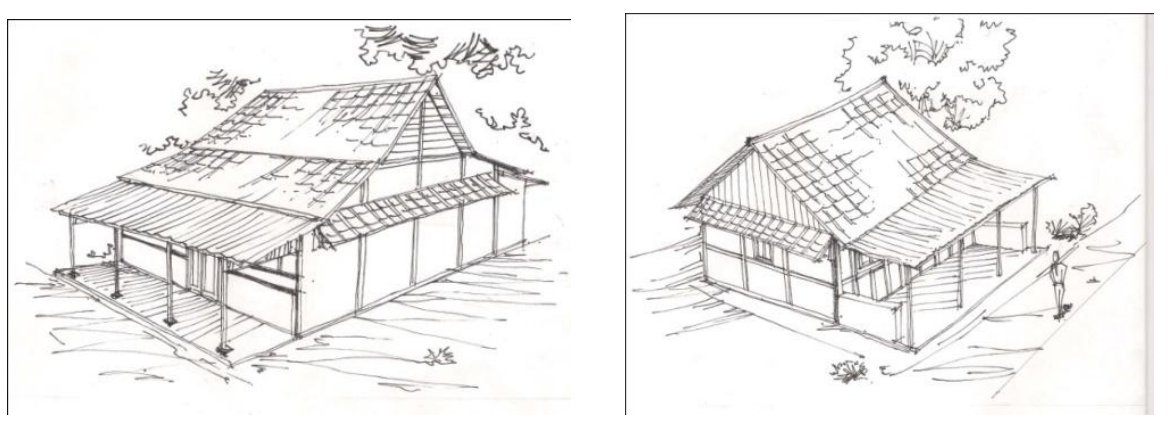

Gambar 9. Massa Rumah Tinggal dusun Ngluwuk

b. Sintaksis Ruang

Ruang ruang permukiman terdiri dari ruang terbuka dusun dan ruang terbuka antar kelompok kluster, antar kluster dan halaman rumah tinggal. Ruang terbuka dusun dibentuk oleh sebuah massa berongga (Gardu jaga), pepohonan dan bidang bidang tegak massa rumah tinggal.
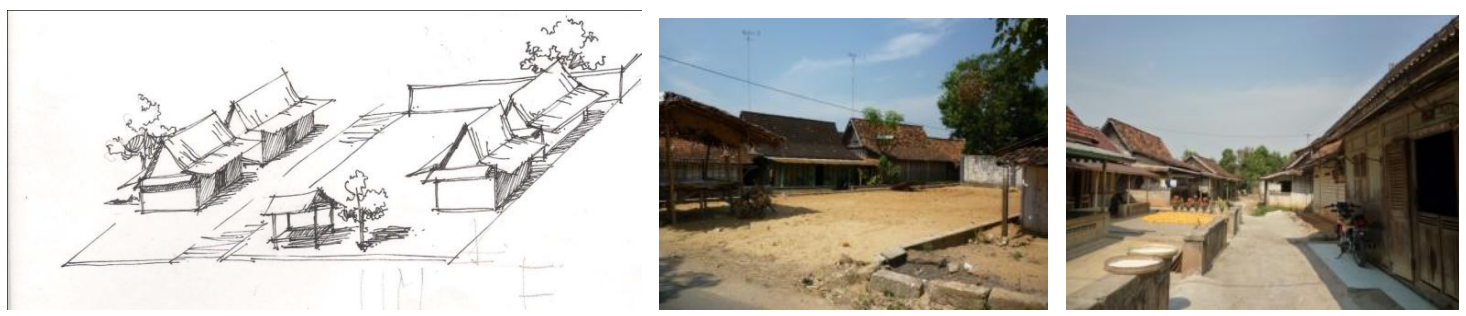

Gambar 10. Ruang terbuka permukiman dusun Ngluwuk

Ruang terbuka yang lain berupa ruang antar kelompok kluster dibentuk oleh pagar tembok pendek dan pepohonan, sedangkan ruang terbuka antar kluster dibentuk oleh tembok pendek sebagai batas Halaman rumah tinggal dan atau bidang bidang muka bangunan rumah tinggal yang berbanjar saling berhadapan. Ruang antar sisi Rumah tinggal berupa lorong lorong dibentuk oleh bidang bidang sisi tegak rumah tinggal atau pagar dan pepohonan. 

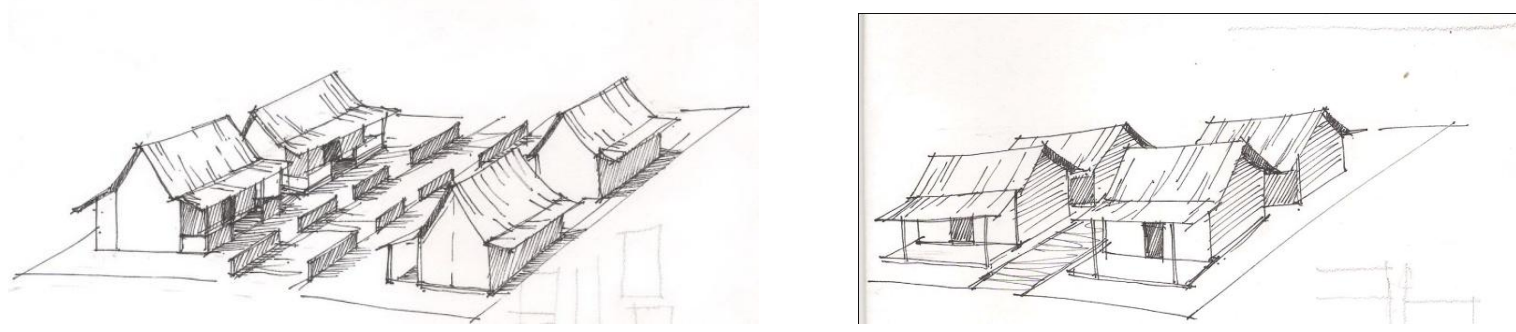

Gb 11. Ruang antar klaster dusun Ngluwuk (kiri) dan lorong Klaster dusun Ngluwuk (kanan)

Ruang ruang Rumah Tinggal berupa halaman, terasan, serambi depan,serambi tengah dan serambi belakang. Susunan Ruang terdapat empat bentuk yaitu bentuk yang pertama, terdiri atas Halaman, serambi depan dan serambing belakang. Halaman, Serambi depan dan serambi belakang dibentuk oleh bidang bidang tegak tertutup, kecuali ada bukaan pintu ditengah serambi depan dan antara serambi depan dan serambi belakang.

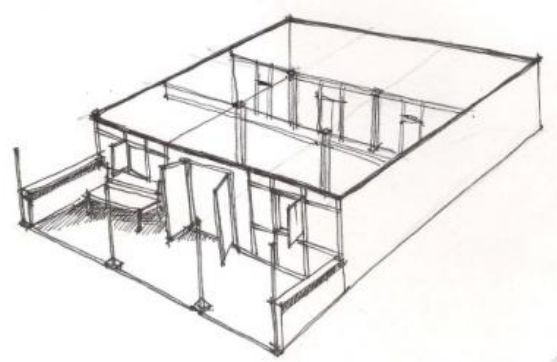

Gambar 12. Ruang Rumah Tinggal tipe 1

Bentuk yang kedua, terdiri dari halaman, serambi depan, serambi tengah dan serambi belakang. Serambi depan dibentuk oleh bidang bidang tegak tertutup kecuali ada bukaan pintu dan jendela kiri, kanan pintu dan bidang serambi tengah yang semi terbuka berupa pilar pilar dan atau ada batas bidang setinggi setengah badan orang. Serambi tengah dibentuk oleh bidang semi terbuka dan bidang bidang tertutup kecuali bidang tertutup yang mempunyai bukaan pintu pintu bidang ruang belakang. Bentukan serambi belakang sama dengan bentukan serambi belakang bentuk pertama.

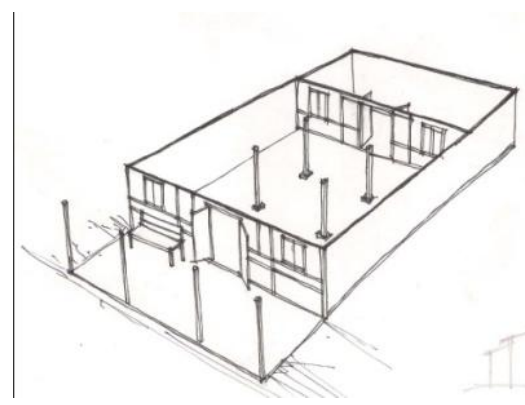

Gambar 13. Ruang Rumah Tnggal tipe 2

Bentuk yang ketiga sama dengan bentuk yang kedua hanya ditambah ruang teras. Bentuk ruang terasan dibentuk oleh bidang terbuka hanya ada pilar dan atau ditambah dinding tegak pendek dan bidang tegak tertutup, sebagian terbuka berupa pintu masuk dan atau jendela di sisi kiri kanan bukaan pintu.Bentuk yang ke empat sama dengan bentuk yang kedua, namun tanpa halaman dan tanpa terasan. 

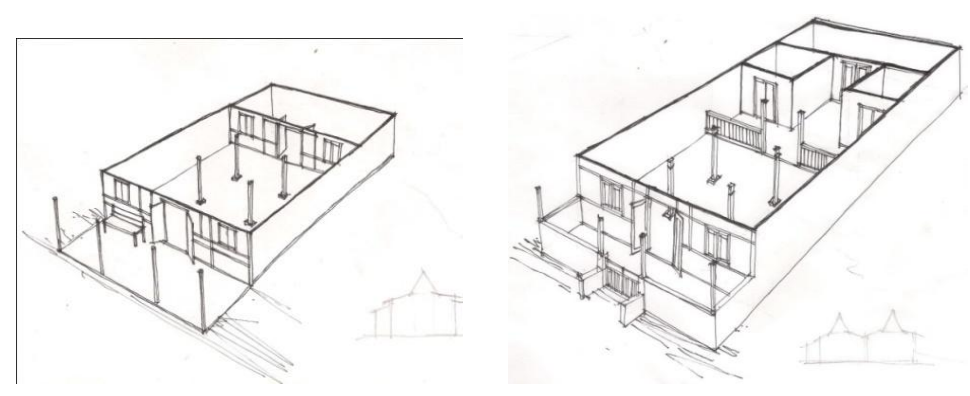

Gambar 14. Ruang Rumah Tnggal tipe 3 \& 4 . dusun Ngluwuk

\section{c. Sintaksis Fungsi}

Ruang terbuka dusun yang berada diujung dusun, berfungsi sebagai tempat kegiatan sosial, budaya penduduk dusun berupa perayaan, kesenian dan olahraga. Ruang terbuka antar kelompok kluster, disamping sebagai jalur sirkulasi antar dusun dan kelompok kluster juga berfungsi sebagai pasar ikan dadakan penduduk sekitarnya di tepi jalan. Ruang terbuka antar klaster disamping sebagai jalur sirkulasi, juga berfungsi sebagai tempat interaksi antar penghuni yang ada di klasternya. Ruang terbuka antar sisi rumah tinggal yang sempit berfungsi sebagai batas antar rumah tinggal, juga berfungsi sebagai jalur sirkulasi antar rumah tinggal sekitarnya.

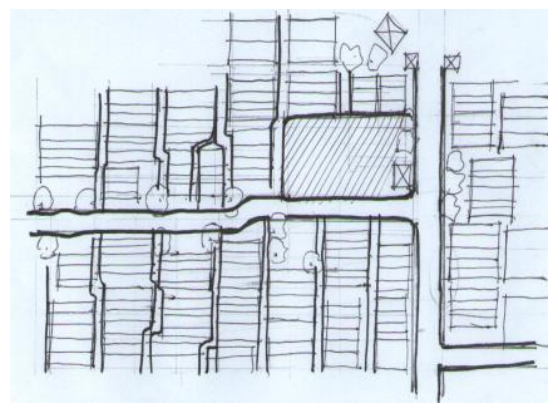

Gambar 15. Fungsi Ruang ruang permukiman dusun Ngluwuk

Rumah tinggal penduduk pada umumnya yang terdiri dari halaman, terasan, serambi depan, serambi tengah dan serambi belakang mempunyai fungsi fungsi tertentu, tergantung mata pencaharian dan kegiatan keseharian mereka.
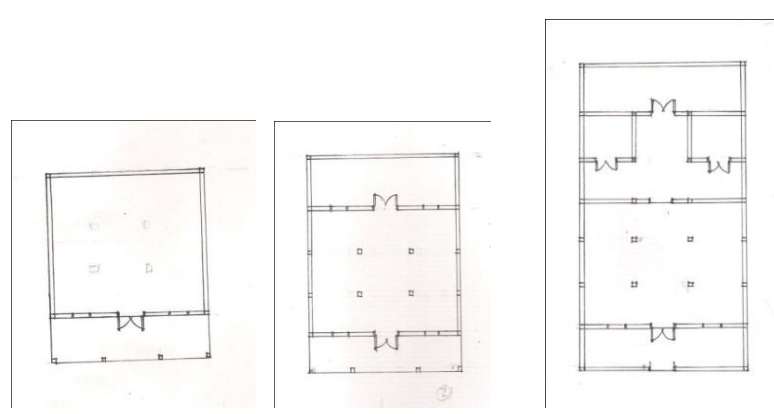

Gambar 16. Fungsi Ruang ruang rumah tinggal dusun Ngluwuk

\section{d. Sintaksis Konstruksi}

Dalam lingkungan permukiman terdapat bangunan Pintu gerbang dusun atau kelompok kluster berupa gapura disusun dengan konstruksi batu bata yang di kapur putih atau diplester. Bangunan gardu yang terletak di ruang terbuka dusun atau di sudut klaster dusun dibangun dengan konstruksi bambu dengan atap genteng tanah, sedangkan lapangan terbuka dusun dibangun dengan konstruksi hamparan tanah dan 
batu yang ditumbuk. Jalur jalur sirkulasi dusun umumnya diperkeras dengan aspal, jalan antar klaster diperkeras dengan plesteran semen dan lorong lorong antar massa rumah tinggal dibangun dengan perkerasan tanah dan batuan. Bangunan pagar batas dusun dan kelompok klaster dibangun dari pasangan tembok bata yang diplester.

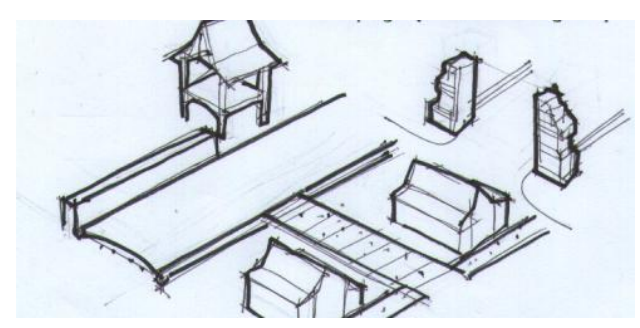

Gambar 17. Konstruksi permukiman dusun Ngluwuk

Konstruksi bangunan rumah tinggal di dusun Ngluwuk ini, sebagian besar menggunakan bahan kayu jati dan sebagian besar pula dari bangunan rumah tinggal tersebut terbangun dari konstruksi kayu. Mulai dari umpak, dinding, pintu, jendela sampai pada atap menggunakan konstruksi kayu dengan tata sam-bungan pasak dan takikan. Konstruksi umpak letak berdirinya dinding terdiri dari susunan batu kapur diatas tanah, diletakkan balok balok kayu sekeliling bangunan untuk meletakkan dan mendirikan dinding panil papan kayu.

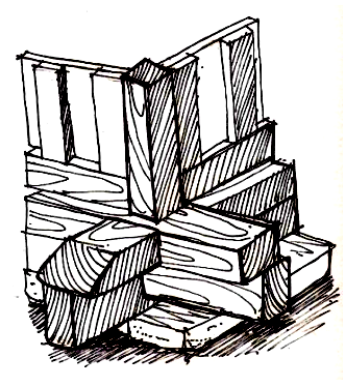

Gambar 18. Konstruksi umpak Rumah tinggal

Konstruksi dinding rumah tinggal terdiri dari susunan papan papan kayu yang dilekatkan pada karangka kayu menjadi panil panil dinding yang disatukan menjadi bidang bidang penutup badan bangunan rumah tinggal yang berdiri terikat pada kolom kolom kayu.
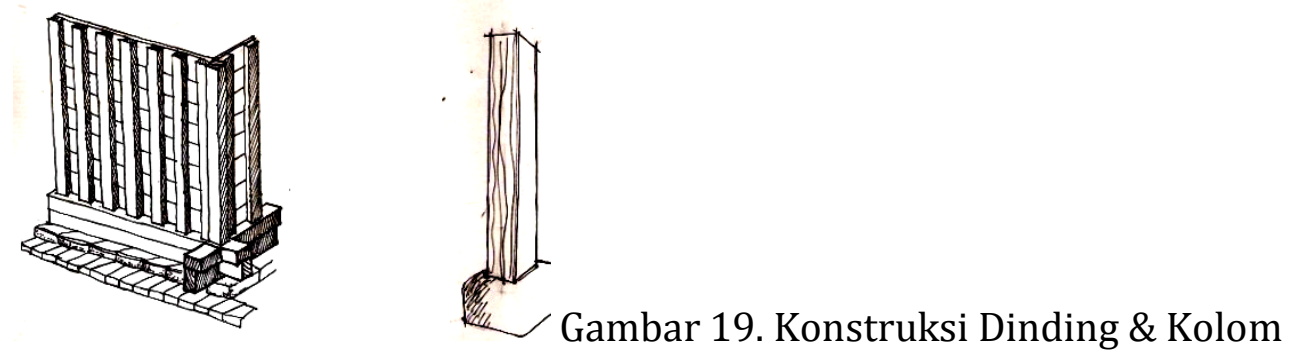

Konstruksi lantai rumah tinggal pada umumnya hanya dari tanah yang diperkeras, masih juga dijumpai lantai tanah keras tersebut dilapisi hamparan sesek bambu. Namun beberapa rumah tinggal sudah banyak pula beralih kepada plesteran dan keramik.

Demikian pula konstruksi atapnyapun seluruh bangunan rumah tinggal di dusun Ngluwuk tersebut menggunakan konstruksi kayu. Kolom kolom soko guru utama ditumpu oleh blandar tegak, membujur dan miring untuk meletakkan kasau 
kasau dan reng rengan yang kesemuaanya dari bahan kayu. Sedangkan penutup atapnya kesemuanya menggunakan genteng tanah, kecuali tritisan sebagian kecil menggunakan seng gelombang.

\section{Kesimpulan}

Konfigurasi visual dan interelasi elemen elemen Arsitektural dari skala lingkungan Kampung, rumah tinggal dan ragam hiasnya pengrajin batik Gedok terdapat keragaman dan keseragaman yang khas. Konfigurasi Visual tersebut memiliki makna dan arti bagi kehidupan mereka dalam menjalankan hidup kesehariannya, terbukti di setiap ruang terdapat konfigurasi visual yang tertentu sesuai persepsi yang dinyatakan dan disikapinya. Konfigurasi visual tersebut juga memiliki fungsi bagi kehidupan mereka dalam menjalankan hidup kesehariannya, terbukti disetiap ruang terdapat konfigurasi yang tertentu sesuai dengan kegiatan yang dilakukannya. Hasil studi konfigurasi visual Arsitektur Permukiman dan Rumah Tinggal Tradisional dan sejenis perlu di dokumentasi, disosialisasi dan diimplemntasikan bagi masyarakat akademik maupun profesional agar budaya fisik maupun non fisik yang masih ada dapat dilestarikan dan dikembangkan.

\section{Daftar Pustaka}

Atmadjaja.Srisusana. Jolanda,(Desember 2003)," Estetika bentuk sebagai pendekatan Semiotika pada penelitian Arsitektur", jurnal Desain \& Konstruksi, Vol 2, No.2.

Allsopp, Bruce,(1977)," A Modern Theory of Architecture', Routledge \& Kegan Paul, London, Henley Boston.

Carlson, Allen, ,(2000)," Aesthetics and The environment", by Roudledge, New york.

Dharma. Agus," Semiotika dalam Arsitektur",http//staffsite.gunadarma. ac.id/agus dh/

Moore. T. Gary,s (1985) Environmental Design Research Directions . Printed in United State of America. by Praeger Pbublisher.

Nasar.L.Jack," Environmental Aesthetics"(1992), Cambriage University press. USA.

Preziosi, Donald,"The Semiotics of the Built Environment', (1979) Indiana University press, london.

Prijotomo, Josef, ,(1984),"Ideas and Forms of Javanese Architecture', gajah mada university press, Yokyakarta.

Rapoport, Amos, (1982)," The meaning of the Built Environment', Sage Publications,Inc, london, England.

Rapoport, Amos, (1969)," House form and Culture", prentice hall, Inc. Englewood, New york.

Sachari,Agus,(2005),' Pengantar Metodologi Penelitian Budaya Rupa", penerbit Erlangga, Jakarta.

Schulz, Christian Nobert. (1984) The Concept of Dwelling, New York.Electa/Rizzoli.

Schulz,Christian Nobert,(1988). Architecture Meaning and Place, New York.Electa/Rizzoli,

Siregar.G.laksmi,(2006)," Makna Arsitektur", Universitas indonesia press, Jakarta.

Snyder James C .(1984). Architectural research. New York. by Van Nostrand Reinhold Company Inc.

Tuan, Yi-Fu. (1976).Topophilia. Copyright. Minnesota Press.

Tuan, Yi-Fu, (1977). Space and Place. Copyright. Minnesota Press.

Wong, Wucius," Beberapa Azas merancang Dwi-Matra", Penerbit ITB, Bandung, 1986.

Wong, Wucius," Beberapa Azas merancang Tri-Matra", Penerbit ITB, Bandung, 1989.

Zahnd, Markus,(2009)," Pendekatan dalam perancangan arsitektur", penerbit kanisius, Soegiapranata University press, semarang.

Zeisel. John. (1984). Inqiry by Design, Tool for Environment-Behavior Research. Cambridge University Press. 